\title{
Uterine Corpus Soft Tissue Neoplasm
}

National Cancer Institute

\section{Source}

National Cancer Institute. Uterine Corpus Soft Tissue Neoplasm. NCI Thesaurus. Code C40179.

A benign or malignant mesenchymal neoplasm of the uterine corpus. Representative examples include leiomyoma, leiomyosarcoma, and endometrial stromal sarcoma. 